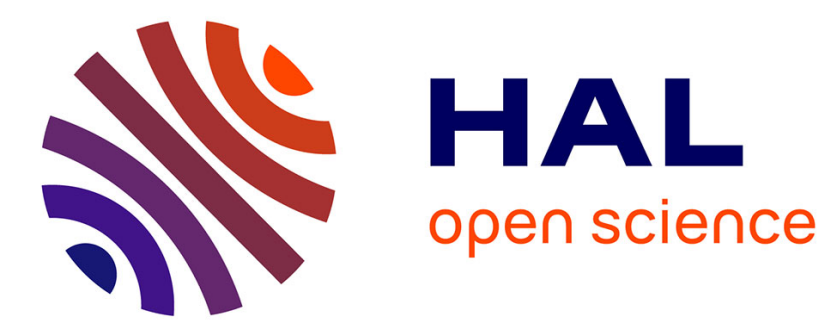

\title{
Intracontinental subduction: a possible mechanism for the Early Palaeozoic Orogen of SE China
}

Michel Faure, Liangshu S. Shu, Bo Wang, Jacques Charvet, Flavien Choulet, Patrick Monié

\section{- To cite this version:}

Michel Faure, Liangshu S. Shu, Bo Wang, Jacques Charvet, Flavien Choulet, et al.. Intracontinental subduction: a possible mechanism for the Early Palaeozoic Orogen of SE China. Terra Nova, 2009, 21, pp.360-368. 10.1111/j.1365-3121.2009.00888.x . hal-00420901

\section{HAL Id: hal-00420901 https://hal.science/hal-00420901}

Submitted on 21 Dec 2009

HAL is a multi-disciplinary open access archive for the deposit and dissemination of scientific research documents, whether they are published or not. The documents may come from teaching and research institutions in France or abroad, or from public or private research centers.
L'archive ouverte pluridisciplinaire HAL, est destinée au dépôt et à la diffusion de documents scientifiques de niveau recherche, publiés ou non, émanant des établissements d'enseignement et de recherche français ou étrangers, des laboratoires publics ou privés. 


\title{
Accepted for publication in TERRA NOVA
}

Intracontinental subduction: a possible mechanism for the Early Palaeozoic Orogen of SE China.

Michel FAURE ${ }^{1,2}$, Liangshu SHU ${ }^{3}$, Bo WANG ${ }^{3}$, Jacques CHARVET ${ }^{1}$, Flavien CHOULET $^{1}$, and Patrick MONIE ${ }^{4}$

1: Université d'Orléans, CNRS/INSU, Université François Rabelais - Tours, Institut des Sciences de la Terre d'Orléans - UMR 6113, Campus Géosciences, 1A rue de la Férollerie 45071 Orléans cedex 2, France (michel.faure@univ-orleans.fr)

2: State Key Laboratory of Lithospheric Evolution, Institute of Geology and Geophysics, Chinese Academy of Sciences, Beijing 100029, China

3: Dept. of Earth Sciences, Nanjing University, Nanjing, China

4: Géosciences Montpellier, UMR 5243, Université de Montpellier 2, 34095 Montpellier, France

Key words : Intracontinental belt, Decollement, Crustal melting, Intracontinental subduction, SE China, Early Paleozoic

\begin{abstract}
The Early Palaeozoic Orogen of SE China consists of three litho-tectonic elements, from top to bottom: a sedimentary Upper Unit, a metamorphic Lower Unit and a gneissic basement. The boundaries between these units are flat lying, south directed, ductile decollements. The lower one is coeval with an amphibolite facies metamorphism (M1). The belt is reworked by migmatite-granite domes, high-temperature metamorphism (M2) and granitic plutons related to post-orogenic crustal melting. We date here the syn-M1 ductile shearing at $453 \pm 7 \mathrm{Ma}$ by $\mathrm{U}-\mathrm{Th} / \mathrm{Pb}$
\end{abstract}


method on monazite. Previous ages, and our new ${ }^{40} \mathrm{Ar} /{ }^{39} \mathrm{Ar}$ ages of biotites and muscovites show that the metamorphic rocks experienced syn-M2 exhumation from 440 Ma to 400 Ma. The Early Palaeozoic Orogen of SE China is an intracontinental belt in which decollements accommodated the north-directed subduction of the Cathaysian continent. This orogen is an example of intracontinental subduction that was not preceded by oceanic subduction.

\section{Introduction}

Continental subduction accounts for high-pressure metamorphism, ductile deformation and melting of crustal rocks. This process is well documented in collision belts where magmatic arc and ophiolitic nappes show that oceanic subduction precedes continental one (e.g. Mattauer, 1986; Escher and Beaumont, 1997; Matte et al., 1997; Guillot et al., 2003, Faure et al., 2008). In intracontinental belts, evidence for an earlier, long lasting, oceanic subduction is lacking. The Central Asia ranges result of intracontinental subduction caused by the indentation of Asia by India after the collision (Mattauer, 1986; Burtman and Molnar, 1993; Avouac et al., 1993; Allen et al., 1999), but these orogens do not expose their deep zones. The Pyrenees or Alice Springs belts are examples of intracontinental orogens where metamorphic or magmatic domains are observed (e.g. Teyssier, 1985; Roure et al., 1989; Hand and Sandiford, 1999). This paper presents structural and geochronological data that allow us to propose an intracontinental subduction model accounting for the formation of the Early Palaeozoic Orogen of SE China.

\section{An outline of the geology of SE China}

The South China Block (SCB, Fig. 1A) is one of the continental masses that amalgamated to form Eurasia. It contains several internal belts, such as the Xuefengshan, or the Wuyi-Yunkai Fold Belt (Fig 1A). SCB experienced five main tectonic events since the Proterozoic. The earliest one corresponds to the Neoproterozoic Jinning Belt that welded the Yangtze and Cathaysia Blocks to form the SCB (Guo et al., 1985, 1989; Chen et al., 1991; Xu et al., 1992; Charvet et al., 
1996; Shu and Charvet, 1996). From 830 to 690 Ma, the intracontinental Nanhua rift, characterized by up to $5 \mathrm{~km}$ of terrigeneous and volcanic rocks, superimposes upon the Jinning Belt (Li et al., 1999; Wang and Li, 2003). There is no major sedimentary break between late Neoproterozoic and Cambrian rocks, but sharp facies and thickness contrasts are recognized for the Cambrian-Ordovician deposits between the northern and southern domains. The former is represented by ca $4.5 \mathrm{~km}$ of carbonate and black shale, whereas the latter consists of more than $8 \mathrm{~km}$ of sandstone, siltstone and mudstone. In the southern domain, Silurian deposits are missing, and Devonian conglomerates and sandstone unconformably cover Early Paleozoic series (JBGMR, 1984, HBGMR, 1988; Zhao et al., 1996). Excepting the area that experienced the Early Palaeozoic Orogeny, the Devonian rocks cover the Silurian rocks either in direct continuity or with a slight disconformity. The Devonian-Carboniferous transition is also continuous. Platform sedimentary sedimentation continues in the Permian, Early and Middle Triassic. A Late Triassic regional unconformity argues for the Late Permian to Middle Triassic Indosinian Orogeny (e.g. Huang, 1945; Faure et al. 1996, Shu et al., 2006; Wang et al., 2007; Lin et al., 2008). The Jurassic-Cretaceous Yanshanian event is characterized by NE-SW trending normal or wrench faults that controlled pluton emplacement and continental sedimentation (e.g. Gilder, 1991; Jahn et al., 1990; Faure et al., 1996; Lin et al. 2000; Zhou et al., 2006; Shu et al., 2008). In the study area, the post-Devonian deformation is localized along faults and does not significantly disturb older structures. A discussion of the Indosinian and Yanshanian events is beyond the scope of this paper.

In SE China, the existence of Early Palaeozoic tectonics is documented by the Devonian unconformity, and Late Silurian to Early Devonian granitoids intruding folded Early Palaeozoic rocks (e.g. Grabau, 1924; Huang 1945; Ren et al. 1989; Zhang et al., 1984; Guo et al, 1985). The tectonics of SE China have been variously interpreted, namely i) Triassic collision between the Yangtze and Cathaysia Blocks (Hsu et al., 1990); ii) Andean-type subduction followed by collision (Ma, 2006; Jahn et al., 1990); iii) multiple arc collisions (Guo et al., 1969; Ma, 2006); iv) intracontinental belt (Ren et al., 1969; Charvet et al., 1996; Wang et al., 2007; Shu et 
al. 2008). However these models do not provide detail structural information.

\section{The Early Palaeozoic Orogen of SE China}

The Early Palaeozoic Orogen is exposed from Wuyi to Yunkai in China and in the Song Chai massif of Vietnam (Fig. 1A). In the study area, South of Nanchang, we recognized five units (Fig. 1B).

The Sedimentary Upper Unit consists, from top to bottom, of Middle to Late

Ordovician turbidite with slumps, disrupted sandstone beds and pebbly mudstones.

Plurimeter-scale limestone lenses scattered within sandstone are likely olistoliths.

Dykes or lava flows are absent.

The Metamorphic Lower Unit is composed of micaschist, paragneiss and a small amount of quartzite, amphibolite and marble. The protoliths of these rocks are terrigeneous or volcaniclastic rocks. Detrital zircons in paragneiss with 1000- $700 \mathrm{Ma}$ ages argue for a Neoproterozoic protolith (Wan et al. 2006).

The Paleoproterozoic basement consists of biotite-amphibole gneiss, amphibolite, granitic-gneiss, and porphyritic granite. East of the study area, amphibolite yields SHRIMP U/Pb zircon age of 1766 \pm 19 Ma interpreted as the protolith age (Li et al., 2000). Detrital zircons from paragneiss yield U/Pb ages ranging from 3.6 to $2.5 \mathrm{Ga}$ (Yu et al., 2006; Xu et al., 2005).

Metatexites, diatexites and anatectic granitoids developed at the expense of the Lower Unit and Proterozoic basement at the end of the Early Palaeozoic Orogeny (cf. below).

Undeformed biotite granite, two micas leucogranite and porphyritic granodiorite, formed by crustal melting, intrude the Upper and Lower Units (Li et al., 1989; Wang et al., 2007; Zhou et al., 2006).

The Upper Unit is well exposed in the southwestern part of the study area, whereas the Lower Unit, migmatites and basement crop out in the northwestern one (Fig. 1). The bulk architecture of the chain (Fig. 2) shows that the sedimentary Upper Unit overlies the metamorphic Lower Unit that in turn overlies the Proterozoic basement. The Upper Unit-Lower Unit boundary is a widespread flat-lying decollement zone (cf. 
below). The contact between the Lower Unit and the Proterozoic basement is poorly exposed, however, near Jianning, the upper part of the Proterozoic gneiss is mylonitized (cf. below). Migmatites and anatectic granites form several domes deforming the Lower Unit. To the North, from Chongren to Cizhou, the foliation dips at high angle to the North. The northern boundary of the belt is the Jiangshan-Shaoxing fault, North of which the Palaeozoic series is continuous and not deformed before the Devonian.

\section{Deformation and metamorphism in the Early Palaeozoic Orogen}

Thin skinned tectonics in the sedimentary Upper Unit. In Chongyi-Jian area (Fig. 1), the Late Neoproterozoic to Ordovician series is deformed by E-W to NW-SE trending folds overturned to the S or SW (Fig. 3A). NW-SE trending fracture cleavage develops in Ordovician rocks, and slaty cleavage is common in Cambrian ones (Fig. 4). Bedding-cleavage relationships indicate a southwestern vergence of the folds. High angle thrusts are also observed. Open buckle folds predominate in Ordovician rocks and similar, even isoclinal, folds are found in Cambrian-Sinian rocks. A NE-SW trending stretching lineation marked by reorientation of detrital particles sometimes appears in the slates but associated metamorphism is absent. As a whole, the ductile deformation increases downward.

The decollement zone. North of Xingguo (Fig. 1B), subhorizontal slaty cleavage and N-S to N50E stretching lineation are conspicuous (Figs. 3B, 4). Asymmetric pressure shadows, sigmoidal quartz or feldspar clasts and sericite clots indicate a top-to-the-SW shearing. These structures are coeval with sericite or chlorite metamorphism. Isoclinal folds with axes parallel to the lineation formed during the ductile shearing are also found. This high-strain zone is interpreted here as a ductile decollement along which the horizontal shortening accommodated by folding and thrusting in the sedimentary Upper Unit is transferred.

The synmetamorphic polyphase deformation in the Lower Unit. Micaschist, quartzite and paragneiss that widely develop in the east of the study area exhibit two synkinematic metamorphic assemblages (M1 and M2). The youngest and most 
conspicuous M2 event is represented by biotite-garnet-sillimanite-muscovite oriented along the macroscopic foliation. Mica and sillimanite form a N-S to NW-SE trending mineral lineation. According to geological maps (JBGMR, 1984), this foliation defines several 20 to $30 \mathrm{~km}$-scale dome structures. In the centre of the domes, anatectic granite presents a foliation represented by schlierens, mafic enclaves (Fig. 3C) and preferred orientation of mica and feldspar. This foliation is parallel to the one observed in migmatites and metamorphic rocks. Along the mineral lineation, biotite or quartz pressure shadows and sigmoidal micas indicate contrasted kinematics depending on their location in the dome. The southern and northern flanks of the dome exhibit top-to-the S and top-to-the N senses of shear, respectively. In Cizhu area, the migmatitic gneiss is overlain by Neoproterozoic-Cambrian sandstone or black shale of the Upper Unit. The boundary between these two units is a south-dipping detachment fault with a N-S stretching lineation and top-to-the-south kinematic indicators.

In the Nancheng and Chongren areas, evidence for migmatization is absent, but the north-dipping foliation is deformed by north directed extensional shear bands and sigmoidal biotite porphyroblasts indicate a top-to-the-North shearing (Fig. 3E). This post-folial deformation developed at the end of M2 event, as indicated by $\mathrm{Ar} / \mathrm{Ar}$ dating (cf. below).

Furthermore, relict porphyroblasts of staurolite, kyanite, garnet, and biotite inclusions in garnet (JBGMR, 1984) argue for an early M1 metamorphism. Locally, sillimanite develops at the expense of kyanite. The high temperature M2 event overprints the medium pressure M1one. The pressure-temperature evolution from medium to high-pressure conditions (11-12kb, 550-600 $\left.{ }^{\circ} \mathrm{C}\right)$ to high temperature ones (4-4.4 kb, $570-650^{\circ} \mathrm{C}$ ) has already been determined in the Wuyi area (Zhao and Cawood, 1999). As the M1 assemblages are mostly erased by the M2 event, the M1-related microstructures are rare. Kyanite defines a N-S trending lineation, but the kinematics is unclear. As a hypothesis, we suggest that the syn-M1 lineation is coeval with the lineation observed in the decollement zones. The thermo-barometric estimates proposed by Zhao and Cawood (1999) and our own dating (cf. below) are used to 
construct a P-T-t path for the Lower Unit (Fig. 4).

Deformation of the Proterozoic basement. A few hundred of meters below the contact with the Metamorphic Lower Unit, the basement gneiss is penetratively foliated and contains a N-S trending mineral lineation marked by biotite clots and amphibole needles (Fig. 3D). Quartz and feldspar form elongated ribbons alternating with mafic minerals. Asymmetric K-feldspar porphyroclasts indicate a top-to-the-S sense of shear.

\section{Geochronological constraints}

Available radiometric dating and our new data allow us to settle the timing of the main events of the Early Palaeozoic Orogeny. The post-tectonic granitoids between Jingganshan and Chongyi yield U/Pb zircon ages of 387£ 4 Ma, 397+/- 4 Ma and 434×5Ma (JGGMR, 1984; Li et al., 1989; Li, 1994; Shen et al. 2008). The M2 metamorphism and coeval anatexis is estimated around 450-420 Ma from U/Pb zircon ages of Cizhu (432 $\pm 4 \mathrm{Ma})$, Lichuan (444 $\pm 4 \mathrm{Ma})$, and granites east of the study area

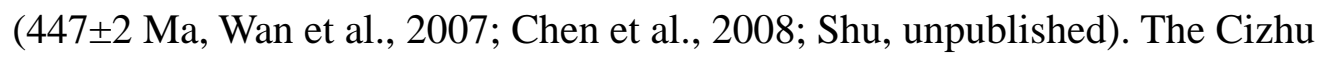
anatectic granite, coeval with the M2 event, yields a muscovite ${ }^{40} \mathrm{Ar} /{ }^{39} \mathrm{Ar}$ age at $421 \pm 8$ Ma (Shu et al., 1999).

Presently, the M1 metamorphism is undated, therefore, in order to place time constraints on the early metamorphic event, monazite was dated by the chemical U-Th/Pb method (Cocherie and Albarède, 2001). The analyzed quartz-biotite-garnet micaschist, located near Chongren (Fig. 1), formed during the M1 event. M2 sillimanite is absent. $\mathrm{U}$, Th and $\mathrm{Pb}$ contents measured by EPMA in ten monazite grains are plotted in the Th/Pb vs. U/P diagram (Fig. 6). The analytical points define a regression line close to the $453 \pm 7 \mathrm{Ma}$ isochron interpreted as the age of the M1 event. ${ }^{40} \mathrm{Ar} /{ }^{39} \mathrm{Ar}$ laser probe, single grain step-heating dating was carried out on a muscovite-biotite pair from the same sample where those micas are deformed by top-to-the-N shear bands. The analytical procedure is described in Brichau et al. (2007). Data are reported in table 1. Both micas provide relatively concordant age 
spectra for a large percentage of the argon released with very few evidence of argon loss or excess argon. Plateau ages of $397 \pm 4$ Ma and $405 \pm 4$ Ma have been calculated for biotite and muscovite, respectively (Fig. 7). These ages are interpreted to date final cooling of this micaschist through a temperature window of about $400-300{ }^{\circ} \mathrm{C}$ as the unit was progressively exhumed at the end of the M2 event.

\section{Tectonic interpretation and a possible geodynamic evolution model}

The above described tectono-metamorphic events are restricted to the South of the Jiangshan-Shaoxing fault (JSF, Fig. 1), North of which, the sedimentary series is continuous from Late Neoproterozoic to Early Triassic, deformed by NE-SW striking upright folds before the Late Triassic unconformity (JBGMR, 1988). Silurian rocks, concordant with Ordovician ones, are covered by Middle Devonian deposits with a disconformity lower than $20^{\circ}$. Therefore, the JSF appears as a major tectonic boundary for the Early Palaeozoic Orogen. Furthermore, Palaeozoic arc-type plutons or volcano-sedimentary rocks are missing.

The metamorphic Lower Unit and the basement are reworked by a high-temperature and melting event. The top-to-the-north kinematics observed in the northern part of the belt coeval with the M2 event, develops during the exhumation of the M1 metamorphic rocks. The Upper and Lower Units cannot be considered as nappes, as younger and less metamorphosed rocks always superimpose upon older ones. Thus, the boundaries between the three elements are decollement zones rather than thrust contacts.

The Jiangshan-Shaoxing Fault does not represent an ophiolitic suture zone, but a tectonic "scar" corresponding to the place where a piece of continental lithosphere of Cathaysia has been subducted to the north below another piece of the same continent (Fig. 8). A tectonic scenario is proposed here (Fig. 8). From the Late Neoproterozoic to Middle Ordovician, the site of the Early Palaeozoic Orogen was occupied by a subsiding trough corresponding to the Nanhua Rift, and to the Early Palaeozoic facies transition. 
In the Late Ordovician, ca 460-450 Ma, two main, south-directed, ductile decollement zones accommodate North-South shortening. The upper decollement, devoid of metamorphism, separates the Upper and Lower Units. The lower one separates the metamorphic Lower Unit from the basement. These high strain zones correspond to rheologically weak interfaces such as Neoproterozoic pelites or the contact between the crystalline basement and the overlying sedimentary rocks. The northern boundary of the deformed block is the JSF scar. The synsedimentary structures in the Ordovician turbidite argue for a tectonic instability that might reflect the onset of the deformation.

In Early Silurian, (ca 445-430 Ma), the deep part of the orogen is exhumed coevally with the development of the high temperature M2 metamorphism and anatexis. The detail of temperature rise is not settled yet. The erosion of the belt provided the material for the Silurian sandstone in the northern domain as indicated by NW-directed scour marks (Rong et al., 2003). However, the ${ }^{40} \mathrm{Ar} /{ }^{39} \mathrm{Ar}$ ages suggest that exhumation continued up to Early Devonian.

\section{Conclusion}

The Early Palaeozoic Orogen of SE China lacks ophiolites, magmatic arc, subduction complexes, high-pressure metamorphism, thus it cannot be a collision belt. Conversely, ductile decollements, medium pressure/medium temperature metamorphism, and crustal melting are conspicuous. The structural, metamorphic and sedimentary elements presented here characterize an intracontinental orogen controlled by the northward subduction of Cathaysia. Pre-orogenic sedimentary and structural inheritances play certainly an important role in the localization and initiation of continental subduction (e.g. Cloetingh et al., 2008).

\section{Acknowledgements}

This research has been supported by National Natural Science Foundation of China (No. 40634022). M. Faure acknowledges also the State Key Laboratory of Lithosphere Tectonic Evolution, Institute of Geology and Geophysics, Academy of 
Sciences, Beijing for the material support and enlightening scientific discussions.

\section{References}

Allen, MB., Vincent, SJ., and Weeler,PJ., 1999. Late Cenozoic tectonics of the Kepingtage thrust zone: interaction of the Tien Shan and tarim basin, NW China. Tectonics, 18, 639-654.

Avouac, JP., Tapponnier, P., Bai, M., You, H. and Wang G., 1993. Active thrusting and folding along the northern Tien Shan and late Cenozoic rotation of the Tarim relative to Dzungaria and Kazakhstan. J. Geophys. Res., 98, 6755-6804.

Brichau, S., Respaut, P. and Monié, P., 2007. New age constraints on emplacement of the Cévenol granitoids, South French Massif Central. Int. J. Earth Sci, doi :10.1017/s00531-007-0187x.

Burtman, V. and Molnar, P., 1993. Geological and geophysical evidence for deep subduction of continental crust beneath the Pamir, Geol. Soc. America Spec. paper, 281, 1-70.

Charvet, J., Shu, LS., Shi, YS., Guo, LZ. and Faure, M. 1996. The building of South China: collision of Yangtzi and cathaysia blocks, problems and tentative answers. Journal of Southeast Asian Earth Sciences, 13, 223-235.

Chen, J., Foland, K., Xing, F., Xu, X. and Zhou, T. 1991. Magmatism along the southeast margin of the Yangtze Block. Precambrian collision of the Yangtze and Cathaysia Blocks of China. Geology, 19, 815-818.

Chen, C., Lee, C., Hsieh, P., Zeng W. and Zhou, H., 2008. Approaching the age problem for some metamorphosed Precambrian basement rocks and Phanerozoic granitic bodies in the Wuyishan area: application of the EMP monazite age dating. 
Geological Journal of China Universities, 14, 1-15.

Cloetingh, S., Fred Beekman, F., Ziegler, P.A.,Van Wees, JD and Sokoutis D., 2006. Post-rift compressional reactivation potential of passive margins and extensional basins. In: The Nature and Origin of Compression in Passive Margins ( $\mathrm{H}$. Johnson, A.G. Dore, R.W. Gatliff, R. Holdsworth, E.R. Lundin and J.D. Ritchie, eds), Geological Society London Special Publications, 306, 27-70. Doi: 10.1144/SP306.2

Cocherie, A. and F. Albarède, 2001. An improved U-Th-Pb age calculation for electron microprobe dating of monazite. Geochim. Cosmochim. Acta, 65, 4509-4522.

Escher, A. and Beaumont, C., 1997. Formation, burial and exhumation of basement nappes at crustal scale: a geometric model based on the Western Swiss-Italian Alps. J. Struct. Geol. 19, 955-974.

Faure, M., Bé Mézème, E., Cocherie, A., Rossi, P., Chemenda, A. and Boutelier, D., 2008. Devonian geodynamic evolution of the Variscan Belt, insights from the French Massif Central and Massif Armoricain. Tectonics, 27, TC2005, doi.org/10. 1029/ 2007 TC00 2115.

Faure, M., Sun, Y., Shu, L. and Charvet, J., 1996. Extensional tectonics within a subduction type orogen. The case study of the Wugongshan dome (Jiangxi Province, China). Tectonophysics, 263, 77-107.

Gilder, S.,Keller, GR. and Luo, M., 1991. Eastern Asia and the western Pacific timing and spatial distribution of rifting in China. Tectonophysics, 197, 225-243.

Grabau, A., 1924. Stratigraphy of China, part I, Paleozoic and older, Geol. Surv. of 
Agric. and Commerce. Peking.

Guillot, S., Garzanti, E., Baratoux, D., Marquer, D., Mahéo, G. and de Sigoyer, J., 2003. Reconstructing the total shortening history of the NW Himalaya. Geochem., Geophys., Geosyst., 4, 1-10, doi: 10.1029/2002GC000484.

Guo, L., Shi, Y., Ma, R. and Lu, H., 1985. Plate movement and crustal evolution of the Jiangnan Proterozoic mobile belt, southeastern China. Chikyu Kagaku, 39, 156-166.

Guo, L., Shi, Y., Lu, H., Ma, R. and Dong, H., 1989. The pre-Devonian tectonic patterns and evolution of South China. J. Asian Earth Sci., 3, 87-93.

Hand, M. and Sandiford, M., 1999. Intraplate deformation in central Australia, the link between subsidence and fault reactivation. Tectonophysics, 305, 121-140.

HBGMR (Hunan Bureau of Geology and Mineral Resources), 1988, Regional geology of Hunan Province, Geol. Publishing House, Beijing, 726p.

Hsu, K., Li, J., Chen, H., Wang, Q., Sun, S. and Sengor, AMC. 1990. Tectonics of South China: key to understanding West pacific geology. Tectonophysics, 183, 9-39.

Huang, T.K., 1945, On major tectonic forms of China: Geol. Mem. Nat. Geol. Survey China, 20.

Jahn, B., Zhou, XH. and Li, JL., 1990. Formation and tectonic evolution of southeastern China and Taiwan: isotopic and geochemical constraints. Tectonophysics, 183, 145-160. 
JBGMR (Jiangxi Bureau of Geology and Mineral Resources), 1984, Regional geology of Jiangxi Province, Geol. Publishing House, Beijing, 921p.

Li, XH, 1994. A comprehensive U/Pb, Sm/Nd, Rb/Sr and ${ }^{40} \mathrm{Ar} /{ }^{39} \mathrm{Ar}$ geochronological study on Guidong Granodiorite, southeast China: Records of multiple tectono-thermal events in a single pluton. Chemical Geology, 115, 283-295.

Li, XH., Tatsumoto, M., Premo, WR. and Gui, X., 1989. Age and origin of the Tanghu granite, southeast China: results from U-PB single zircon and Nd isotopes. Geology, 17, 395-399.

Li, XH., Sun, M., Wei, G.J., Liu., Lee, CY. and Malpas, J., 2000. Geochemical and Sm-Nd isotopic study of amphibolites in the Cathaysia Block, southeastern China: evidence for an extremely depleted mantle in the Paleoproterozoic. Precambrian Res., 102, 251-262.

Lin, W., Faure, M., Monié, P., Schäerer, U., Zhang, L. and Sun, Y., 2000.Tectonics of SE China, new insights from the Lushan massif (Jiangxi Province). Tectonics, 19, 852-871.

Lin, W., Wang, Q. and Chen, K., 2008. Phanerozoic tectonics of south China block: New insights from the polyphase deformation in the Yunkai massif. Tectonics, TC6004, doi: 10.1029/2007TC002207.

Ma, R., 2006. New thought about the tectonic evolution of the South China : with discussion on several problems of the Cathaysian Old land. Geol. J. of China Univ. 12, 448-456.

Matte, P., Mattauer, M., Olivet, J-L. and Griot, D., 1997.Continental subductions beneath Tibet and the Himalayan orogeny: a review. Terra Nova, 9, 264-270. 
Mattauer, M., 1986, Intracontinental subduction, crust mantle decollement and crustal stacking wedge in the Himalaya and other collision belts. Geol. Soc. London Spec. Pub., 19, 37-50.

Ren, J. and Chen, T., 1989. Tectonic evolution of the continental lithosphere in eastern China and adjacent areas. Journal of Southeast Asian Earth Sciences, 3, 17-27.

Rong, J., Chen, X., Su, Y., Ni, Y., Zhan, R., Chen, T., Fu, L., Li, R. and Fan, J., 2003. Silurian Paleogeography of China, in : Silurian Lands and Seas (E. Landing and M. Johnson, eds.). New York State Museum Bull., 493, 243-298.

Roure, F., Choukroune, P., Berastegui, X., Munoz, JA., Villien, A., Matheron, P., Bareyt, M., Séguret, M., Camara, P. and Deramond, J., 1989. ECORS Deep seismic data and balanced cross sections: geometric constraints on the evolution of the Pyrénées. Tectonics, 8, 41-50.

Shen, WZ., Zhang, FR., Shu, LS. and Wang, LJ., 2008. Formation age, geochemical characteristics of the Ninggang granite body in Jiangxi Province and its tectonic significance. Acta Petrologica Sinica, 24, 2244-2254

Shu, LS. and Charvet, J., 1996. Kinematics and geochronology of the Proterozoic Dongxiang-Shexiang ductile hear zone with HP metamorphism and ophiolitic mélange (Jiangnan Region, China). Tectonophysics, 267, 291-302.

Shu LS., Lu, H., Jia, D., Charvet, J. and Faure, M.. 1999. Study of the ${ }^{40} \mathrm{Ar} /{ }^{39} \mathrm{Ar}$ isotopic age for the early Paleozoic tectonothermal event in the Wuyishan region, S. China. J. Nanjing University, 35, 668-674.

Shu, LS., Faure, M., Jiang, S., Yang Q. and Wang Y., 2006. SHRIMP zircon U-Pb age, 
litho- and biostratigraphic analyses of the Huaiyu Domain in South China. Episodes, 29, 244-252.

Shu, LS., Yu, JH., Jia, D., Wang , B., Shen, W. and Zhang, YQ., 2008. Early Palaeozoic orogenic belt in the eastern segment of South China. Geological Bulletin of China, 27, 1581-1593.

Teyssier, C., 1985. A crustal thrust system in an intracratonic tectonic environment. J. Structural Geol., 7, 689-700.

Wan, Y., Liu, D., Xu, M., Zhuang, J., Song, B., Shi, Y. and Du, L., 2007. SHRIMP $\mathrm{U}-\mathrm{Pb}$ zircon geochronology and geochemistry of metavolcanic and metasedimentary rocks in NW Fujian, Cathaysian block, China: tectonic implications and the need to redefine lithostratigraphic units. Gondwana Res., 12, 166-183.

Wang, J. and Li ZX., 2003. History of Neoproterozoic rift basins in South China: implications for Rodinia break-up. Precambrian Res., 122, 141-158.

Wang, Y., Fan, W., Zhao, G., Ji, S. and Peng, T., 2007. Zircon U-PB geochronology of gneisses in Yunkai Mountains and its implications on the Caledonian event in South China. Gondwana Res., 12, 404-416.

Xu, B., Guo, L. and Shi, Y., 1992. Proterozoic terranes and multiphase collision orogens in anhui-Zhejiang-Jiangxi areas. Geol. Publishing House, Beijing, 112p.

Xu, X., O’Reilly, S., Griffin, W., Deng, P. and Pearson, 2005. Relict Proterozoic basement in the Nanling mountains (SE China) and its tectonothermal overprinting. Tectonics, 24, 1-16. 
Yu, J., Wei, Z., Wang, L., Shu, LS. and Sun, T., 2006. Cathaysia Block: a young continent composed of ancient materials. Geological Journal of China Universities, 12, 440-447.

Zhang, Zh. Liou, J.G. and Coleman, R.G., 1984. An outline of the plate tectonics of China. Geol. Soc. Am. Bulletin, 95, 295-312.

Zhao, X., Allen, M.B., Whitham, A. and Price, S., 1996. Rift-related Devonian sedimentation and basin development in South China. J. Asian Earth Sci., 14, 37-52.

Zhao, G. and Cawood, P., 1999. Tectonothermal evolution of the Mayuan assemblage in the Cathaysia Block: implications for Neoproterozoic collision-related assembly of the South China Craton. Am. J. Sci., 299, 309-339.

Zhou, X., Sun, T., Shen, W., Shu, L., Niu, Y., 2006. Petrogenesis of Mezozoic granitoids and volcanic rocks in south China: a response to tectonic evolution. Episodes, 29, 26-33.

Figure captions

Figure 1A: Tectonic sketch of the South China Block. JLS: Neoproterozoic Jiulingshan belt; XFS: Triassic Xuefengshan Belt; JSF: Jiangshan-Shaoxing Fault. 1B: Structural map of the Early Palaeozoic Orogen in the study area, south of Nanchang (Jiangxi Province). For clarity, sedimentary series and granitic plutons younger than Early Triassic have been omitted. In the Sedimentary Upper Unit, dotted lines represent bedding trajectories. In the Metamorphic Lower Unit, dotted lines outline dome structures. Boxes show the new radiometric ages given in figures 6 and 7. $\mathrm{U} / \mathrm{Th} / \mathrm{Pb} \mathrm{mz}$ : chemical age obtained on monazite (mz), $\mathrm{Ar} / \mathrm{Ar} \mathrm{bi} / \mathrm{ms}:{ }^{40} \mathrm{Ar} /{ }^{39} \mathrm{Ar}$ ages from biotite (bi) and muscovite (ms). 
Figure 2: Synthetic cross section (located in figure 1) showing the bulk geometry of the Early Palaeozoic Orogen.

Figure 3: Some tectonics features of the pre-Devonian orogen of SE China in Jiangxi. A: nearly isopach fold in Cambrian sandstone S. of Jinggangshan. B: Stretching lineation in the decollement layer N. of Xingguo. C: anatectic granitoids near Lichuan, the magmatic foliation is defined by biotite schlierens and preferred orientation of biotitic boudins, note also a gneiss xenolith the foliation of which is oblique to the magmatic one. D: Proterozoic gneiss with a conspicuous planar and linear fabric related to the Early Paleozoic tectonics, N. of Jianning. E: Sigmoidal biotite showing a top-to-the-N sense of shear attributed to the late orogenic exhumation, S. of Chongren. This sample is the one dated by ${ }^{40} \mathrm{Ar} /{ }^{39} \mathrm{Ar}$ (cf. figure 7)

Figure 4: Stereographic plots (Schmidt lower hemisphere projection) of the structural elements related to the Early Palaeozoic orogeny of SE China.

A: poles of bedding (S0) and cleavage (S1) planes in the sedimentary Upper Unit near Chongyi. B: cleavage poles (S1) and strike of stretching lineation in the ductile decollement layer North of Xingguo. C: pole of composite foliation (S1-2) and M2 mineral lineation (L2) mainly represented by sillimanite and biotite around the Cizhou dome.

Figure 5: P-T-t path of the Metamorphic Lower Unit. Time constrains are those provides in this paper (cf. figures 6 and 7), $\mathrm{P}$ and $\mathrm{T}$ conditions are adapted from Zhao and Cawood, (1999).

Figure 6: $\mathrm{U}-\mathrm{Th} / \mathrm{Pb}$ isochron diagram of monazite from a biotite-garnet micaschist belonging to the metamorphic Lower Unit (location $\left.27^{\circ} 42^{\prime} 20,115^{\circ} 59^{\prime} 26\right)$. Analytical procedure and data reduction are provided in Cocherie and Albarede (2001). The calculated regression line (thick line) is similar to the theoretical isochronon (dashed line). The thick lines represent the error envelopes. The calculated age at the centroid 
is $453 \pm 7 \mathrm{Ma}$, which is interpreted as the age of the M1 metamorphism.

Figure 7: Laser probe, single grain step-heating dating of muscovite and biotite from the same biotite garnet micaschist sample belonging to the metamorphic Lower Unit (location $27^{\circ} 42^{\prime} 20,115^{\circ} 59^{\prime} 26$ ). Plateau ages of $397 \pm 4$ Ma and $405 \pm 4$ Ma have been calculated for biotite and muscovite respectively. These ages are interpreted to date final cooling of this micaschist through a temperature window of about $400-300{ }^{\circ} \mathrm{C}$.

Figure 8: A possible geodynamic evolution model of the intracontinental orogen.

A: Early Ordovician reconstruction of the Early Palaeozoic paleogeographic transition from a carbonate platform to terrigeneous trough from North to South. The facies transition zone is independent of the Neoproterozoic collision, but it might represent a potentially weak zone for the development of the Early Paleozoic Orogen. The southern continent, South of the Jinning suture, is Cathaysia. Y: Yangtze Block. B: Late Ordovician northward continental subduction of the Paleoproterozoic basement of the southern part of Cathaysia, decollement of the Lower Unit, and development of the biotite-garnet-kyanite M1metamorphism. South-directed thrusting and folding with a basal ductile decollement layer deform the Neoproterozoic to Ordovician Sedimentary Upper Unit. The deformation does not propagate North of the Jiangshan-Shaoxing fault (JSF). The Jinning suture, lying to the North of the scar, is not reactivated. Second order decollement layers are located in coal measures or in soft mudstone beds separating quartzite or sandstone strata.

C: Early Silurian (444-430 Ma) completion of the northward continental subduction of Cathaysia. Crustal melting and high temperature M2 metamorphism overprint the M1 event. The exhumation of the chain is accommodated by erosion with northward transport to a Silurian turbiditic basin, doming and detachement faulting.

Table 1. Analytical data of laser probe, single grain step-heating dating of muscovite and biotite from the a biotite garnet micaschist sample. 


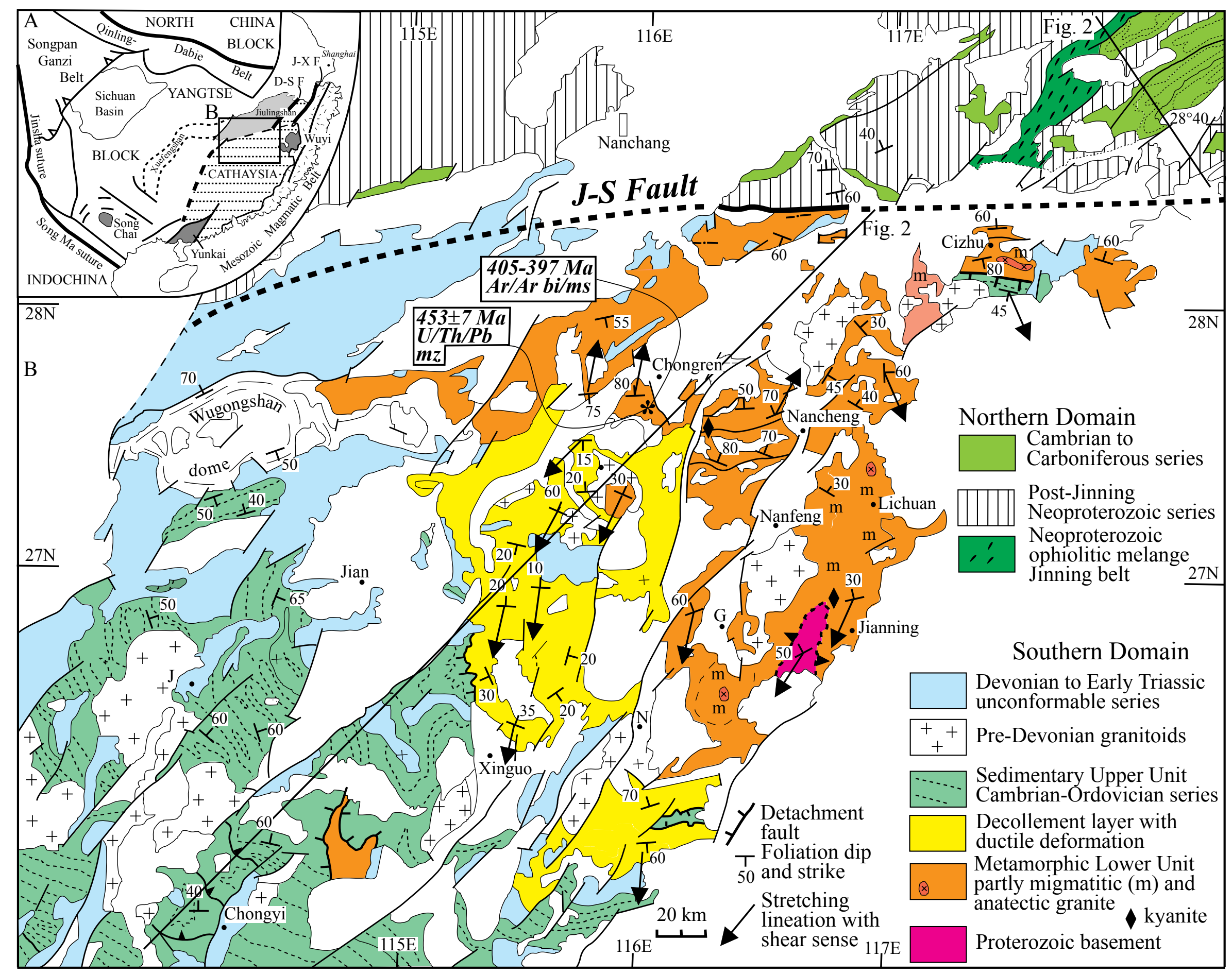

Fig. 1 


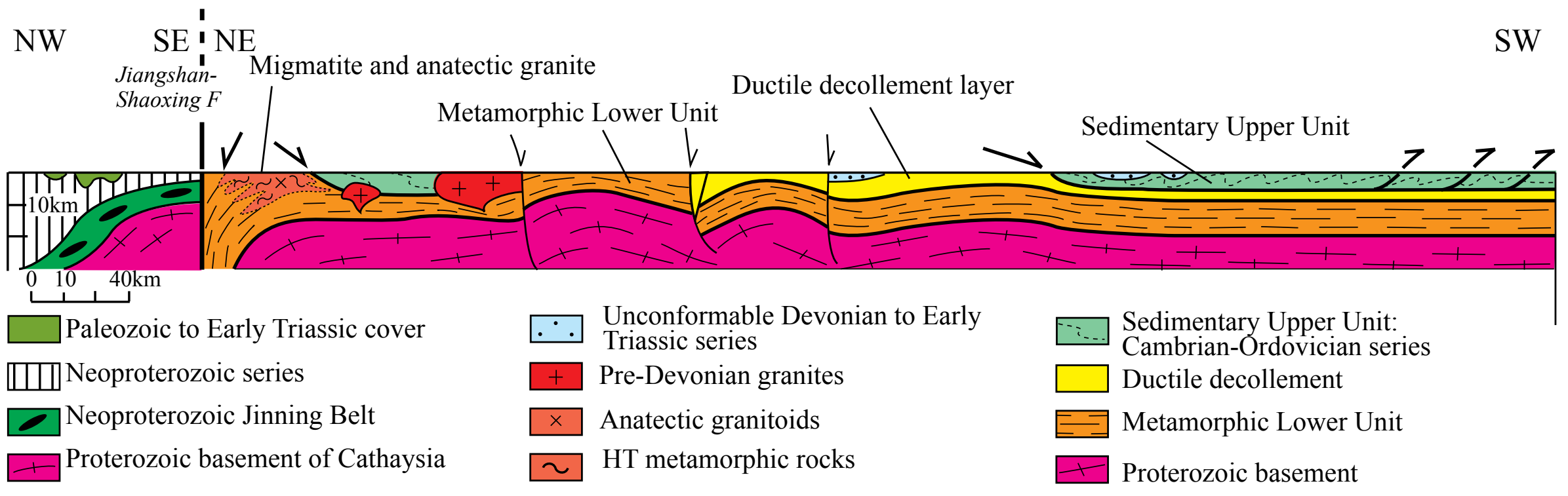




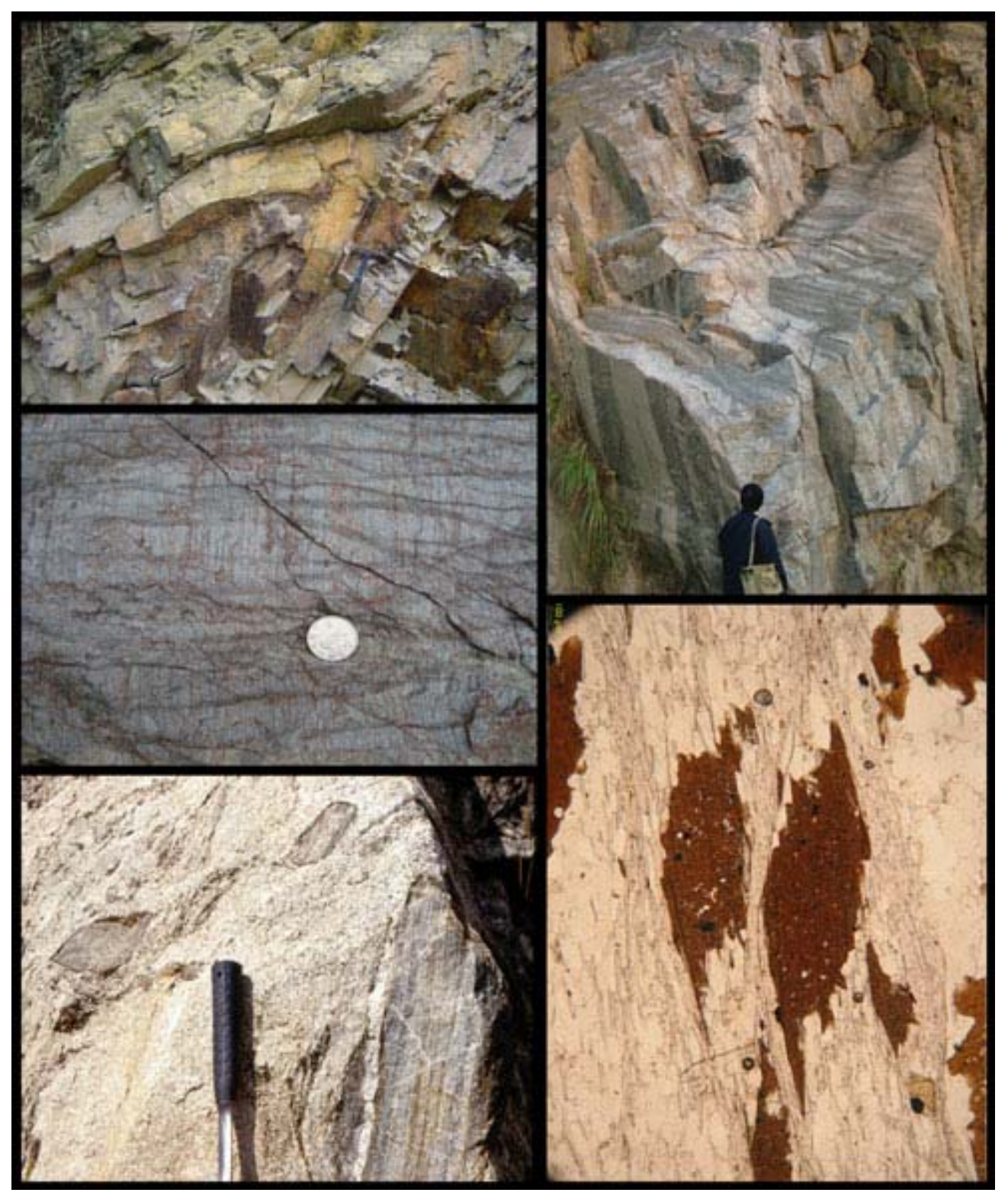

Fig. 3 
A

Sedimentary Upper Unit near Chongyi

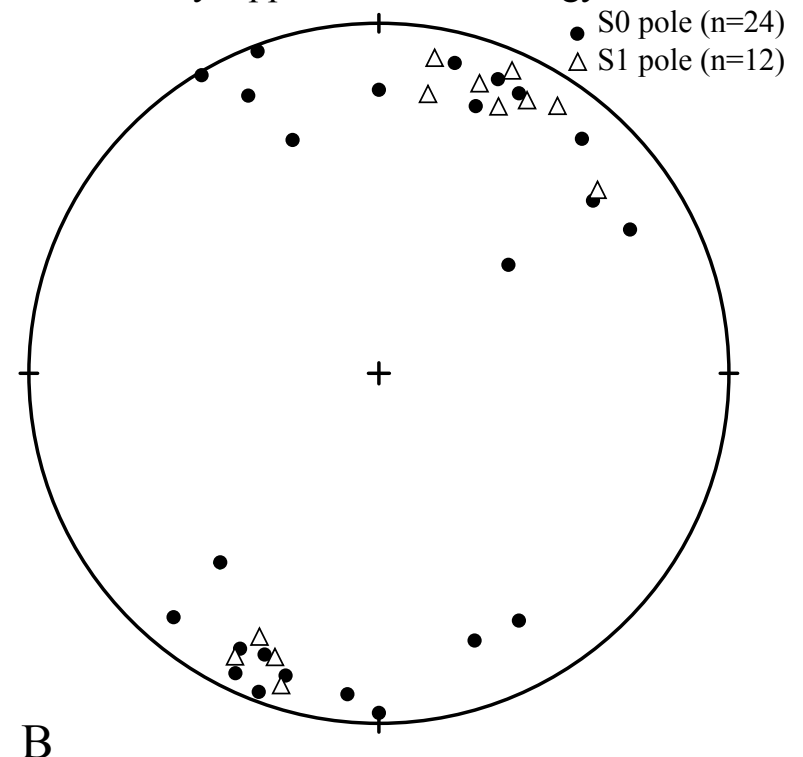

Ductile decollement $\mathrm{N}_{\text {. of }}$ Xinguo $\triangle \mathrm{S} 1$ pole $(\mathrm{n}=20)$

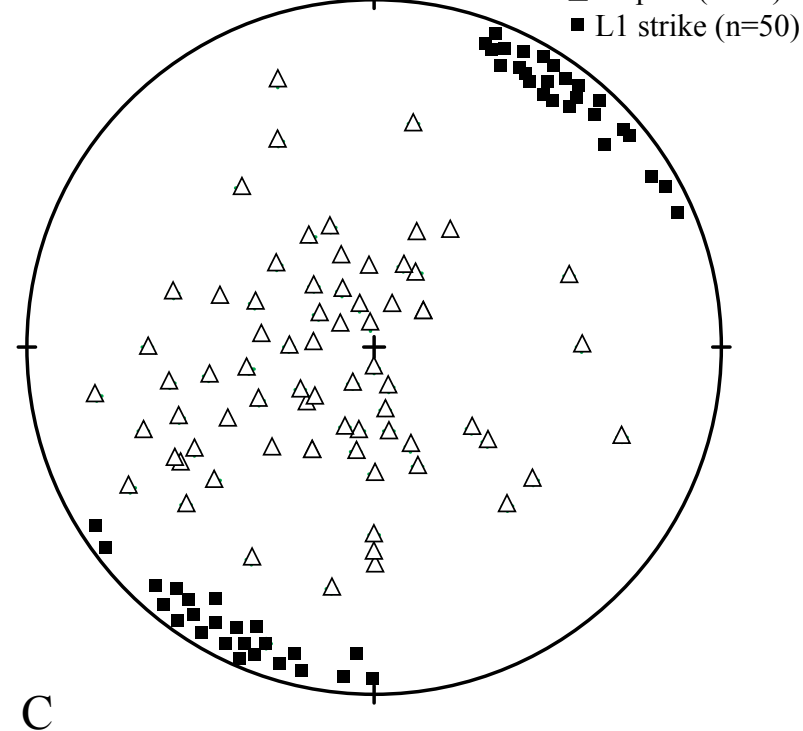

Cizhou Dome

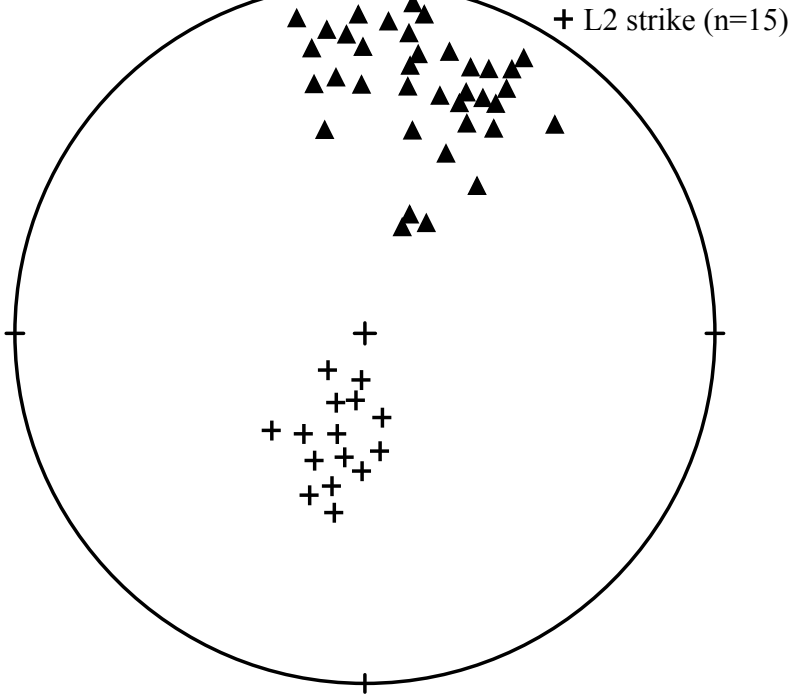

Fig 4. 


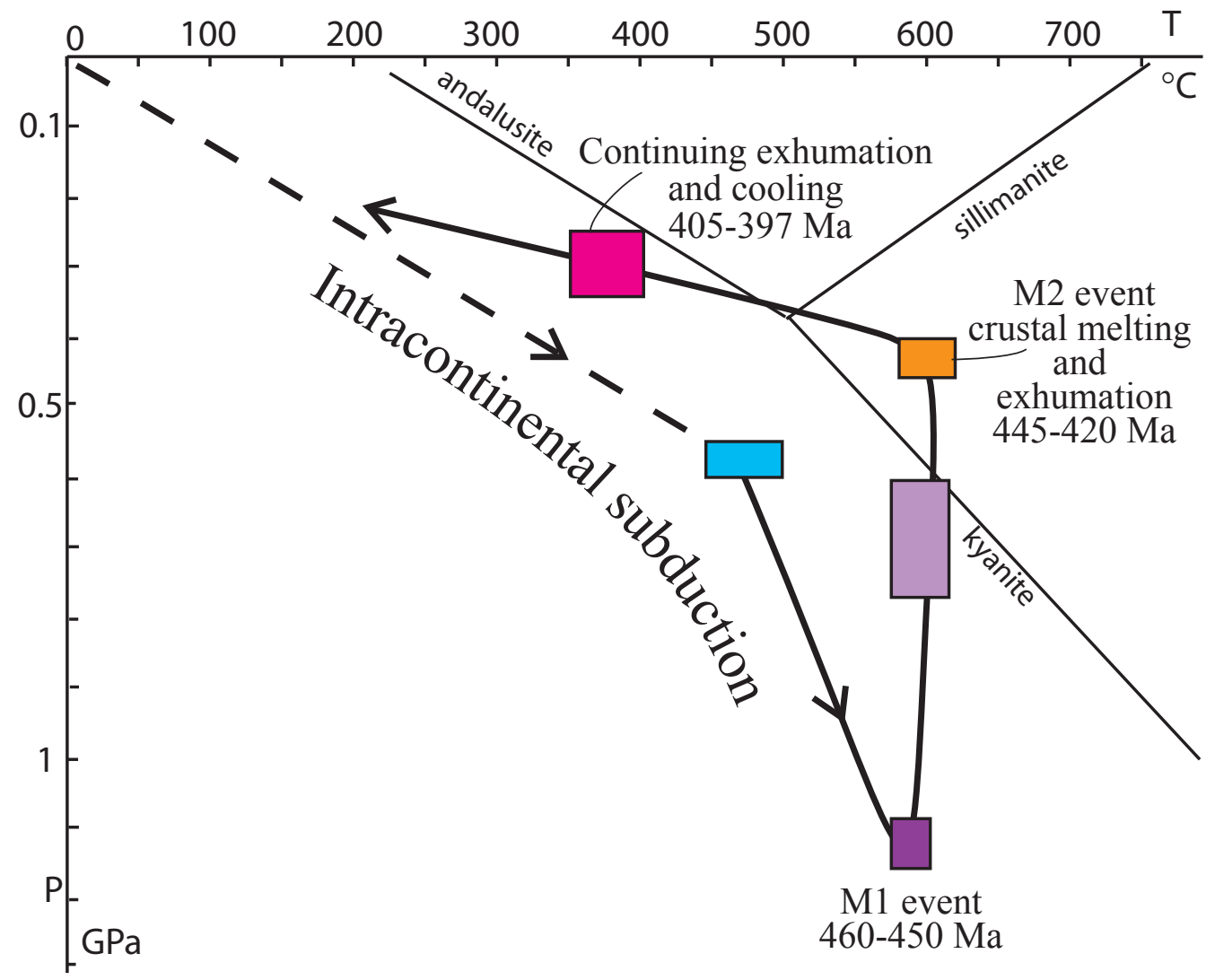




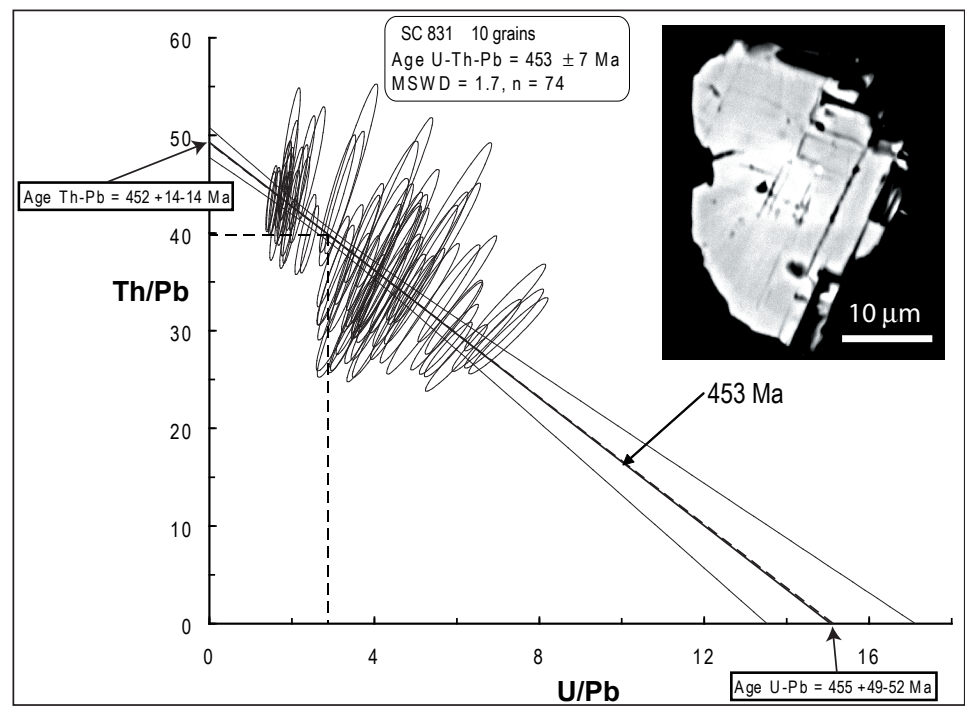

Fig. 6 
Middle Ordovician ca $470 \mathrm{Ma})$ : contrasted sedimentation

Carbonate platform Early Paleozoic terrigeneous trough

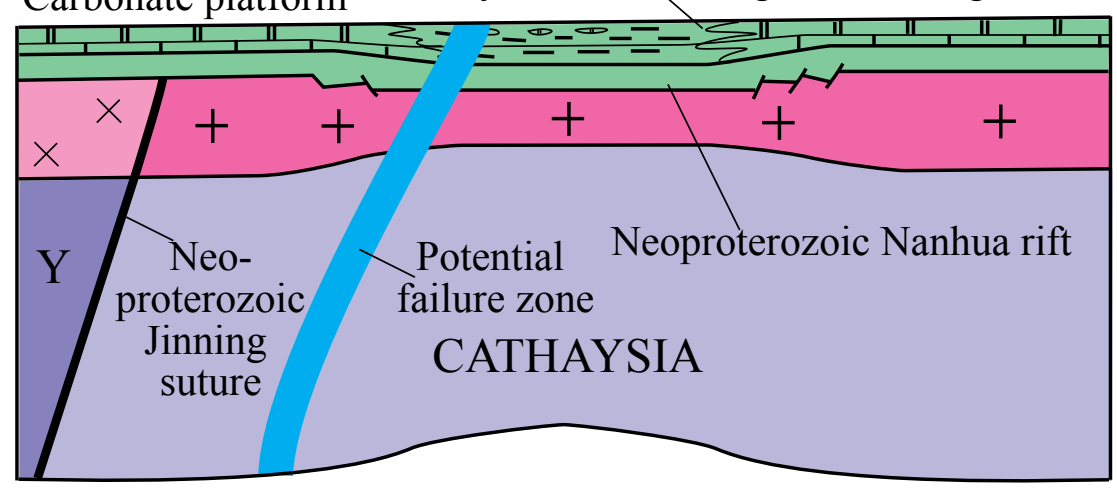

Late Ordovician (460-444 Ma) : Intracontinental subduction

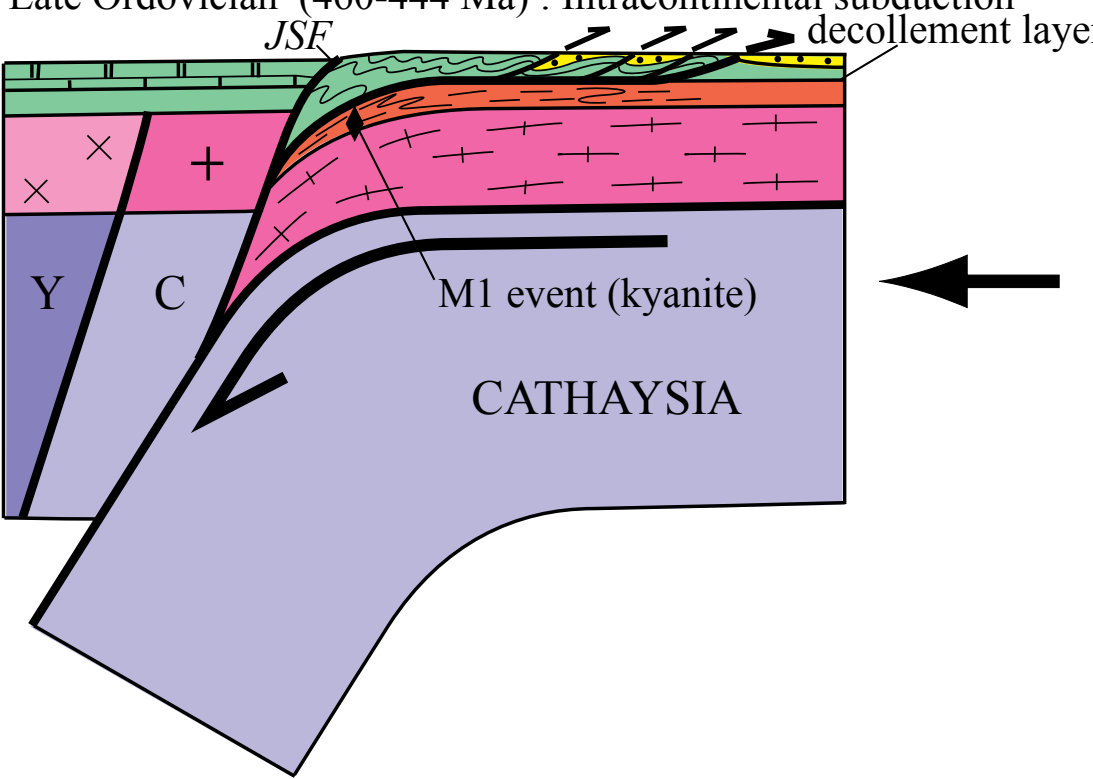

Early Silurian (444-430 Ma) : Erosion and exhumation

Northward transport JSF HT metamorphism-crustal melting of sediments -Detachment fault

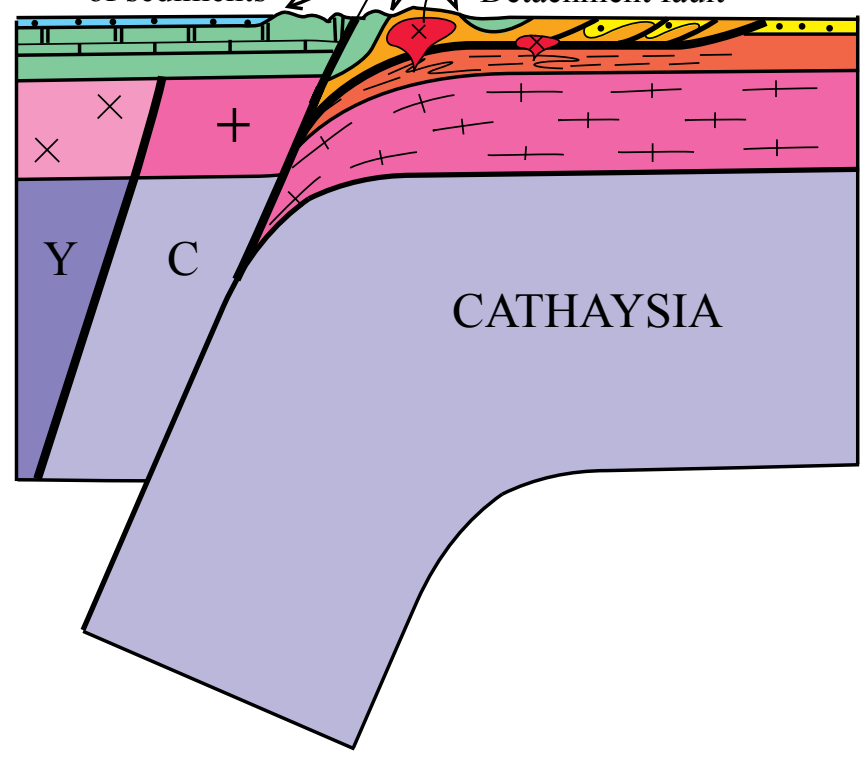

